\title{
NEW NONDESTRUCTIVE WAY OF IDENTIFYING THE VALUES OF PULL-OFF ADHESION BETWEEN CONCRETE LAYERS IN FLOORS
}

\author{
Łukasz SADOWSKI, Jerzy HOŁA \\ Faculty of Civil Engineering, Wroclaw University of Technology, pl. Grunwaldzki 11, \\ 50-377 Wroclaw, Poland \\ Received 09 Jul 2013; accepted 16 Oct 2013
}

\begin{abstract}
This paper presents a new nondestructive way of identifying the values of pull-off adhesion between the concrete layers in concrete floors. It based on the roughness parameters of the base layer surface, using the nondestructive optical technique, and on the floor surface, using the nondestructive acoustic techniques and employing artificial neural networks (ANNs) for this purpose. The new way has a potential for being widely used in practice, whereby it may become possible to employ previously trained ANNs to identify the pull-off adhesion, without impairing the surface of the tested concrete floor.
\end{abstract}

Keywords: concrete, floors, nondestructive tests, surface roughness, acoustic techniques, artificial neural networks.

Reference to this paper should be made as follows: Sadowski, Ł.; Hoła, J. 2014. New nondestructive way of identifying the values of pull-off adhesion between concrete layers in floors, Journal of Civil Engineering and Management 20(4): 561-569. http://dx.doi.org/10.3846/13923730.2014.897642

\section{Introduction}

Floors in buildings consist of a top layer (topping) laid on a base layer (base). In the course of laying, using and renovating a floor, defects and damage may arise at the interface between the two layers (Błaszczyński et al. 2006; Łowińska-Kluge, Błaszczyński 2012; Cwirzen et al. 2014; Siewczyńska 2012; Stawiski 2012; Srinivas et al. 2013; Olofsson et al. 2005; Trapko, Musiał 2011). A major defect, having a significant effect on floor life, is the lack of bond between the topping and the base. This defect is usually due to the improper preparation of the base layer surface.

A tangible measure of this bond is the value of pulloff adhesion $f_{\mathrm{b}}$ practically determined by the seminondestructive pull-off method. It is both a qualitative method, since it enables one to detect a defect (no adhesion) at the interface, and a quantitative method, since using it one can determine pull-off adhesion $f_{\mathrm{b}}$. It is required of concrete floors that pull-off adhesion $f_{\mathrm{b}}$ be not less than $0.5 \mathrm{MPa}$ and that one measurement per $3 \mathrm{~m}^{2}$ should be taken (PN-EN 12636:2001). The drawback of the pull-off method is that damage is caused in each test point, as shown in Figure 1, which then needs to be repaired. This is a serious drawback which leads to the practice of reducing the number of test points used for evaluating floor quality. Considering the above, it seems that in building practice there is a demand for a new way of floor testing which does not cause damage to the tested floor surface.

The proper preparation of the base surface, which can be described using surface roughness parameters, has a significant bearing on pull off adhesion $f_{\mathrm{b}}$ between the concrete layers in floors (Gonzalez-Jorge et al. 2012; Hoła et al. 2012; Mathia et al. 2011; Naderi, Ghodousian 2012; Niemczewska-Wójcik et al. 2013; Pawlus et al. 2013; Perez et al. 2009; Santos, Julio 2013; Sezen, Fisco 2013; Stach et al. 2005; Twardowski et al. 2011; Wieczorowski et al. 2010). The proper preparation of the base surface determines the mechanical adhesion and so the interlayer bond. According to literature reports, the concrete base surface roughness parameters determined prior to top layer concreting can be useful in the nondestructive assessment of the bond between the concrete layers.

From literature reports it also appears that nondestructive techniques can be useful in determining the bond between concrete layers (Bungey et al. 2006; Darowicki et al. 2003; Gołaski et al. 2012; Gorzelańczyk 2012; Grzelka et al. 2012; Helmerich et al. 2012; Hoła, Schabowicz 2010; Maierhofer et al. 2004). First of all, acoustic techniques: the impulse response technique and impact-echo technique can be used for this purpose.

A methodology for the nondestructive assessment of the interlayer bond in concrete floors by means of the above techniques has been developed (Hoła et al. 2011). However, this methodology cannot be used to determine pull-off adhesion $f_{\mathrm{b}}$. Also attempts have been made to determine the correlations between pull-off adhesion $f_{\mathrm{b}}$ and the particular (individual) parameters determined using the optical technique (Sadowski 2013a) and acoustic techniques (Hoła, Sadowski 2012). The attempts have been unsuccessful. 


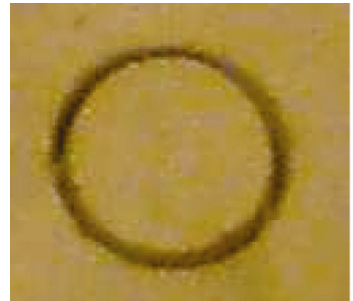

a)

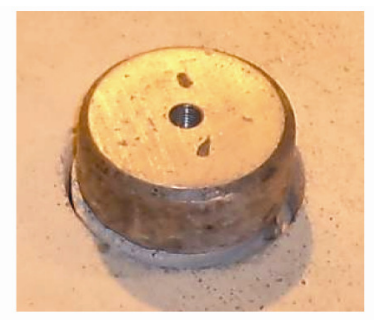

b)

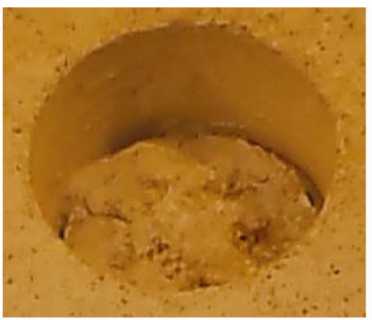

c)

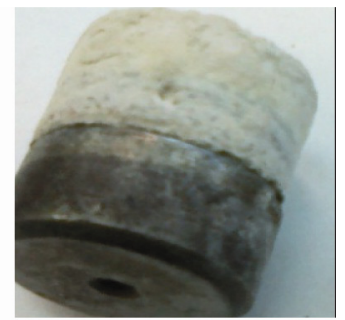

d)

Fig. 1. Damage to floor surface caused by pulling off piece ( $50 \mathrm{~mm}$ in diameter) of it from base: a) incision of concrete piece to be pulled off; b) sticking on special metal disk; c) top layer after test; d) pulled off piece of concrete

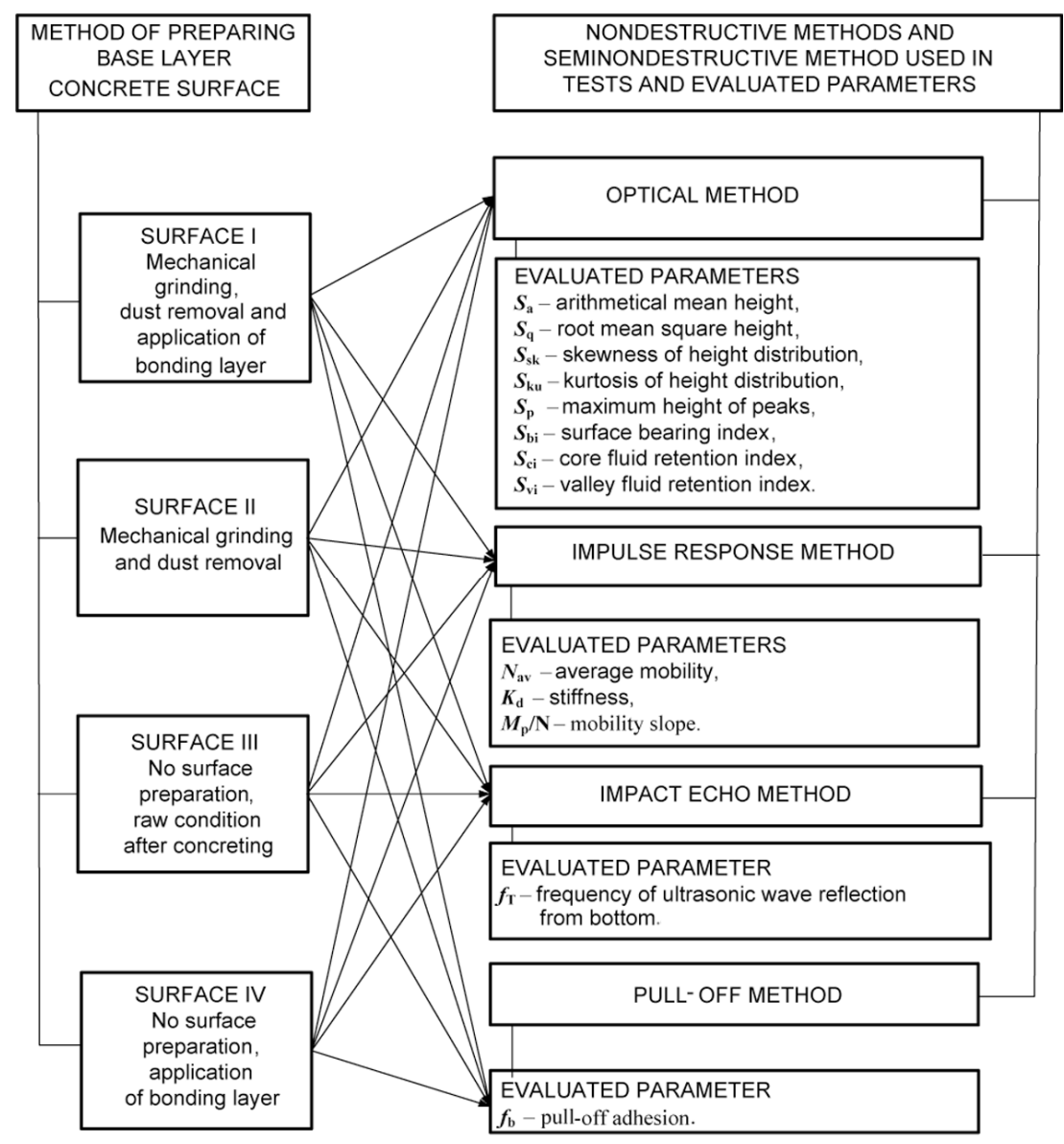

Fig. 2. Scheme of ways of preparing base layer surface in conjunction with investigative nondestructive techniques and seminondestructive technique and parameters evaluated by them (Sadowski, Hoła 2013)

Therefore, a new way of identifying pull-off adhesion values on the basis of a few jointly considered parameters (describing the concrete base layer surface and determined on the surface of the top layer by acoustic techniques) needs to be found.

In order to interrelate a larger number of the parameters it is necessary to employ artificial neural networks (ANNs). In recent years in the literature on the subject one can find numerous documented successful applications of ANNs in building engineering (Chien-Ho 2013; Hoła, Schabowicz 2005; Hasanzadehshooiili et al. 2012; Raab et al. 2013; Sadowski 2013b; Song, Yu 2013).

So far there has been no reliable employment of ANNs for evaluating pull-off adhesion $f_{\mathrm{b}}$ of the concrete layers in floors, on the basis of parameters estimated using nondestructive techniques. An attempt to employ an radial basis function (RBF) artificial neural network was made in Sadowski (2013c), but the obtained values of linear correlation coefficient $R$ were not satisfactory.

\section{Description of tests}

Tests were carried out on two model test specimens no. 1 and 2, representing $2500 \times 2500 \mathrm{~mm}$ concrete floor consisting of a $25 \mathrm{~mm}$ thick top layer laid on a $125 \mathrm{~mm}$ thick base layer. The base layer was laid on a sheet of underlayment membrane and on a 100 thick layer of sand.

The $25 \mathrm{~mm}$ thick top layer was made of grade C20/25 concrete with quartz aggregate of $2 \mathrm{~mm}$ maximum grading. The base layer was made of grade C30/37 concrete with concrete mix consistency S3, w/c $=0.5$ and crushed basalt aggregate of $8 \mathrm{~mm}$ maximum grading. 
In order to differentiate the pull-off adhesion at the top/base layer interface the surface of the base layer was prepared in four versions denoted with Roman numerals from I to IV, as shown in Figure 2. Surfaces no. I and II were produced on model test specimen no. 1 while surfaces no. III and IV were produced on model test specimen no. 2. A ready-made compound (in the form of concentrate to be diluted with water) for priming concrete bases for floorings and toppings was used for the bonding layer. The base layer was primed four hours prior to laying the top layer.

Figure 2 shows a scheme of the ways of preparing the base layer surface in conjunction with the investigative nondestructive techniques and the seminondestructive one and the parameters evaluated by them.

Figure 3 shows a sketch of model test specimens no. 1 and 2, the division of the base layer surface according to the way of preparing it and the arrangement of test points. A grid (with $100 \times 100 \mathrm{~mm}$ mesh size) was marked on the surface of both the base layer and the top layer at a distance of $500 \mathrm{~mm}$ from the edge of each of the specimens. The grid columns were denoted with letters from $\mathrm{A}$ to $\mathrm{H}$ and the rows with successive numbers from 1 to 16 (Sadowski, Hoła 2013).

a)

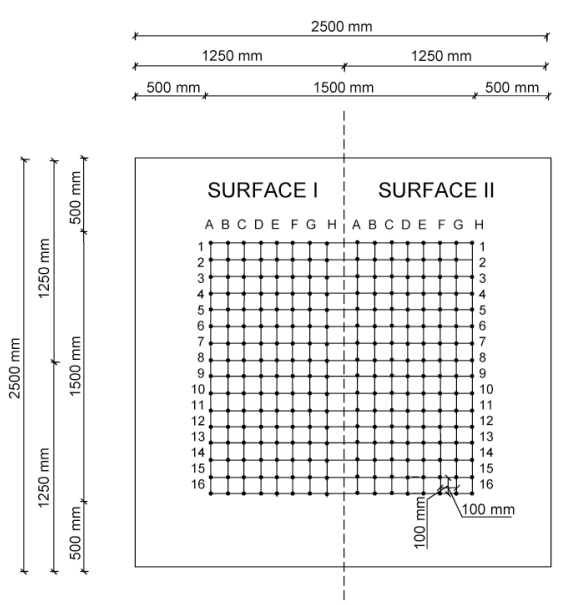

b)

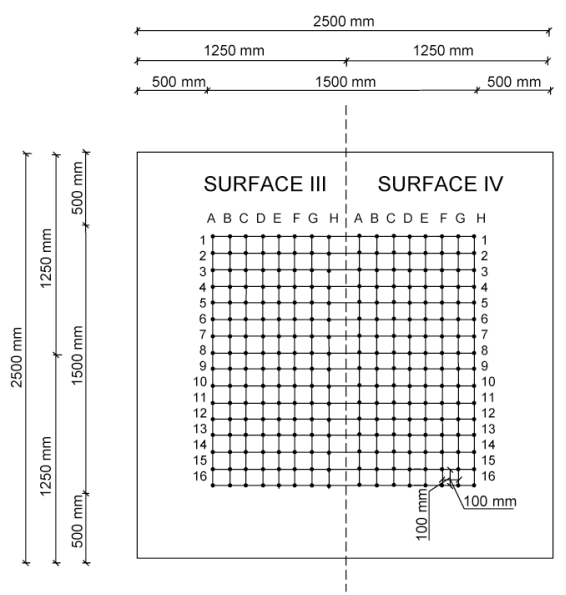

Fig. 3. Division of base layer surface of model test specimen no. 1 (a) and model test specimen no. 2 (b) according to surface preparation method, and arrangement of test points
As described in Sadowski and Hoła (2013), the top layer was concreted 28 days after the base layer had been concreted and the tests were carried out after 90 days of top layer concrete curing.

In Figure 4 a schematic of the rig for investigating the base layer surface roughness by the optical technique using an optical camera, and the actual testing are presented.

a)

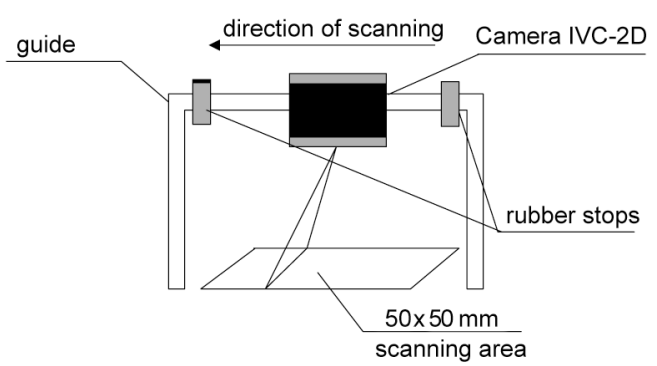

b)

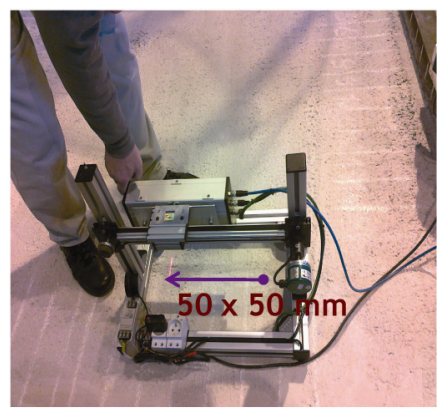

Fig. 4. Schematic of rig for investigating roughness of base layer surface by optical technique using optical camera (a) and actual testing (b)

As described in Sadowski and Hoła (2013), the investigations of the base layer surface were carried out in the previously marked grid points, by means of $1028 \times 768$ pixel resolution camera mounted on a guide. The acquired data were transmitted to software installed on a portable computer. The camera with its lens by default fixed at an angle of $53^{\circ}$, was manually shifted on the guide. The investigations consisted in scanning $50 \times 50 \mathrm{~mm}$ surface profiles at every $0.1 \mathrm{~mm}$. The scanning time of the test area in each grid point did not exceed 2 seconds. As a result, a 3D image of the concrete surface within the test area would be obtained. The data were processed by the software and the following nine concrete surface roughness parameters: $S_{\mathrm{a}}, S_{\mathrm{q}}, S_{\mathrm{sk}}, S_{\mathrm{ku}}, S_{\mathrm{bi}}$, $S_{\mathrm{ci}}, S_{\mathrm{vi}}, S_{\mathrm{v}}$ and $S_{\mathrm{p}}$ were generated.

The investigations on the top layer surface were carried out using nondestructive acoustic techniques: the impulse response technique and the impact-echo technique.

The impulse response tests were carried out using equipment consisting of a calibrated hammer for exciting an elastic wave by striking the hammer against the surface of the tested material, a geophone and software for data recording and processing (Sadowski, Hoła 2013). In Figure 5 a schematic of the rig for impulse-response testing and the actual testing are presented. 
a)

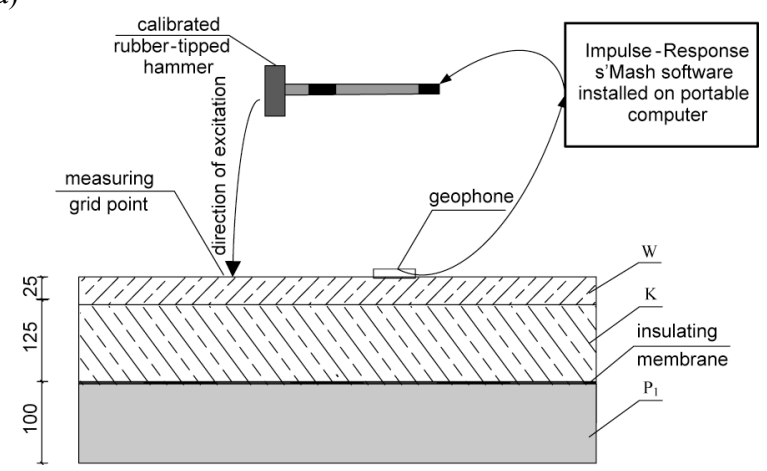

b)

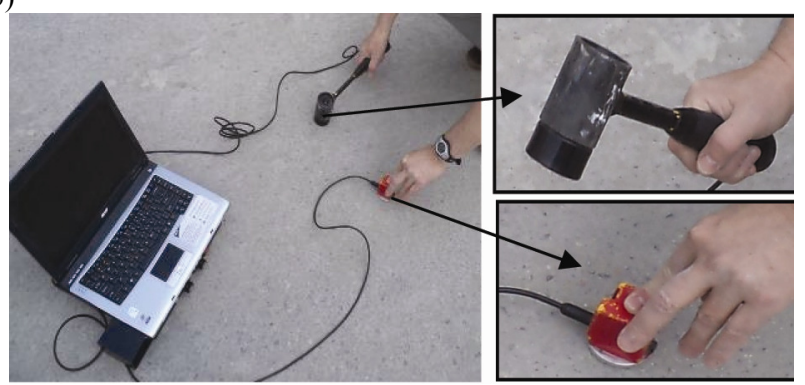

Fig. 5. Schematic of impulse-response test rig (a), and actual testing (b)

The impact-echo tests were carried out using a system consisting of a set of balls with different diameters, used to generate an elastic wave by striking against the surface, a receiving head and a software for recording and processing the data. In Figure 6 a schematic of the rig for impact-echo testing and the actual testing are presented. The tests were carried out in accordance with the recommendations given in Sansalone and Streett (1997).

The following five parameters: $K_{\mathrm{d}}, N_{\mathrm{av}}, M_{\mathrm{p}} / N$ and v, determined by the impulse response technique, and $f_{\mathrm{T}}$ determined using the impact-echo technique, were adopted.

a)

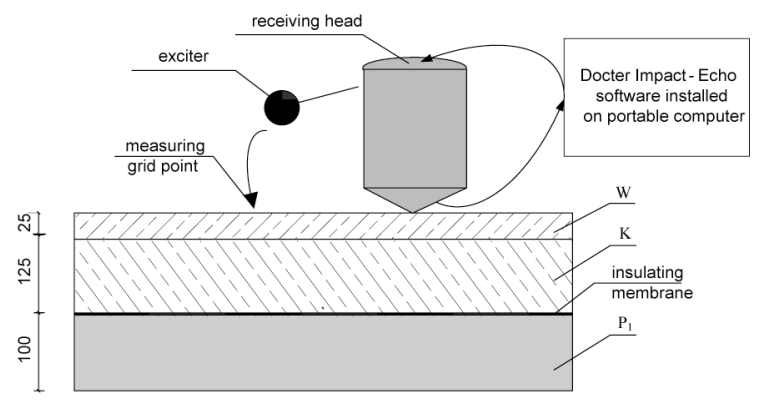

b)

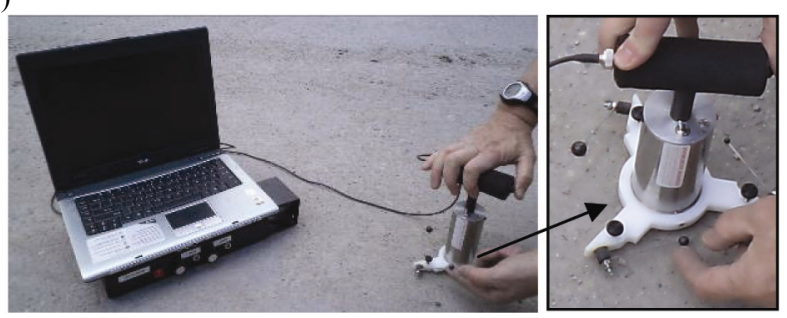

Fig. 6. Schematic of impact-echo test rig (a), and actual testing (b)

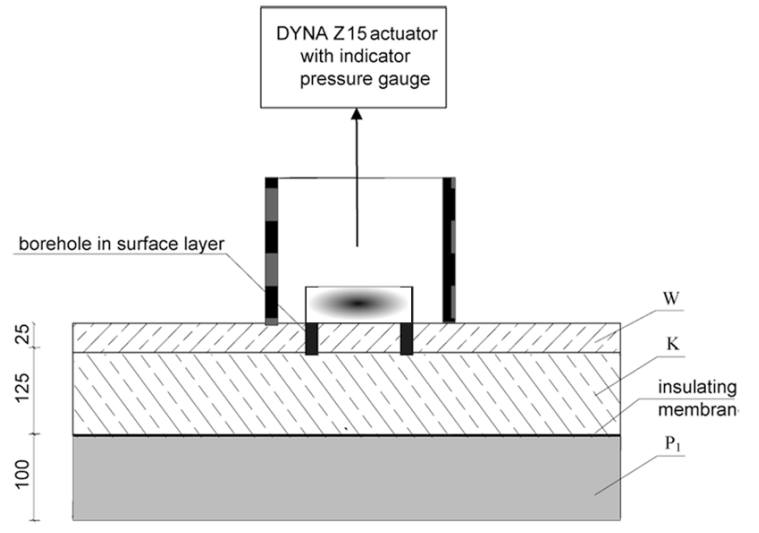

Fig. 7. Schematic of pull-off test rig

As described in Sadowski and Hoła (2013), a schematic of the rig for testing by the seminondestructive pull-off method is shown in Figure 7. The tests were performed in the same points in which the nondestructive tests had been carried out.

Figure 8 shows an example of model test specimen no. 1 after concrete cores had been pulled off from its top layer.

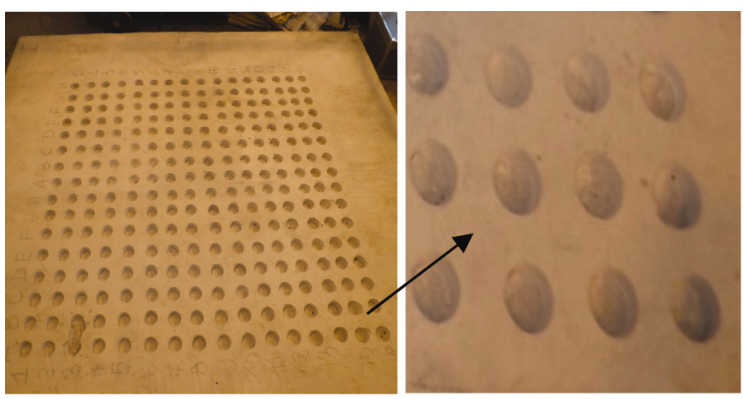

Fig. 8. Examples of model test specimen no. 1 after concrete cores had been pulled off from its top layer

\section{Test results}

Table 1 shows sample parameter values obtained for model specimens no. 1 and 2 for the surfaces from I to IV. The full data can be found in Sadowski (2012). Then the sets (472) of experimental results were subjected to statistical analyses whereby the database was reduced to 460 sets of results constituting input variables for a neural network.

\section{Statistical analyses of test results}

In order to select input variables from the experimentally determined parameters, which would be suitable for the input layer of an artificial neural network, statistical analyses of test results were carried out.

For this reason a test of goodness of fit with the normal distribution was performed in 472 test points for all the parameters obtained by the nondestructive and the seminondestructive methods. The Shapiro-Wilk test was used for this purpose. According to Shapiro and Wilk (1965), if probability level $W$ of the test statistic falls below the fixed test significance level $W_{\mathrm{n}}(\alpha)$, then the hypothesis about the fit with the normal distribution is rejected. 
Table 1. Sample parameter values obtained for surfaces from I to IV of model specimens no. 1 and 2

\begin{tabular}{|c|c|c|c|c|c|c|c|c|c|c|c|c|c|c|c|}
\hline \multirow{4}{*}{$\begin{array}{c}\text { Number } \\
\text { of test } \\
\text { point }\end{array}$} & \multicolumn{15}{|c|}{ Name of test method and parameter symbol } \\
\hline & \multicolumn{9}{|c|}{ Optical technique } & \multicolumn{4}{|c|}{ Impulse response technique } & \multirow{2}{*}{$\begin{array}{c}\begin{array}{c}\text { Impact- } \\
\text { echo } \\
\text { technique }\end{array} \\
f_{\mathrm{T}}\end{array}$} & \multirow{2}{*}{$\begin{array}{c}\begin{array}{c}\text { Pull- } \\
\text { off } \\
\text { method }\end{array} \\
f_{\mathrm{b}} \\
\end{array}$} \\
\hline & $S_{\mathrm{a}}$ & $S_{\mathrm{q}}$ & $S_{\mathrm{sa}}$ & $S_{\mathrm{ku}}$ & $S_{\mathrm{bi}}$ & $S_{\mathrm{ci}}$ & $S_{\mathrm{vi}}$ & $S_{\mathrm{v}}$ & $S_{\mathrm{p}}$ & $K_{\mathrm{d}}$ & $N_{\mathrm{av}}$ & $M_{\mathrm{p}} / N$ & $v$ & & \\
\hline & $\mathrm{mm}$ & $\mathrm{mm}$ & - & - & - & - & - & $\mathrm{mm}$ & $\mathrm{mm}$ & - & $\mathrm{m} / \mathrm{s} \cdot \mathrm{N}$ & - & - & $\mathrm{kHz}$ & $\mathrm{MPa}$ \\
\hline $\mathrm{I} / \mathrm{B} 10$ & 0.500 & 0.267 & -0.478 & 4.686 & 0.040 & 0.697 & 0.024 & 1.311 & 0.694 & 0.017 & 62.674 & 0.828 & 1.116 & 7.500 & 0.970 \\
\hline $\mathrm{I} / \mathrm{B} 11$ & 0.737 & 1.033 & \begin{tabular}{|l|}
-0.582 \\
\end{tabular} & 3.933 & 0.048 & 0.744 & 0.004 & 1.009 & 0.384 & 0.004 & 99.276 & 3.449 & 0.592 & 7.000 & 0.870 \\
\hline $\mathrm{I} / \mathrm{B} 12$ & 0.825 & 0.730 & -0.845 & 4.509 & 0.033 & 0.730 & 0.012 & 1.250 & 0.489 & 0.041 & 57.401 & 1.746 & 0.544 & 8.000 & 0.940 \\
\hline$\vdots$ & $\vdots$ & $\vdots$ & \begin{tabular}{|l|}
$\vdots$ \\
\end{tabular} & $\vdots$ & $\vdots$ & $\vdots$ & \begin{tabular}{|l|}
$\vdots$ \\
\end{tabular} & $\vdots$ & $\vdots$ & $\vdots$ & $\vdots$ & $\vdots$ & $\vdots$ & $\vdots$ & $\vdots$ \\
\hline II/A5 & 0.125 & 0.179 & -2.280 & 11.63 & 0.019 & 0.674 & 0.009 & 1.546 & 0.316 & 0.088 & 449.394 & 0.918 & 1.235 & 5.000 & 0.610 \\
\hline II/A6 & 0.121 & 0.166 & \begin{tabular}{|l|}
-1.763 \\
\end{tabular} & 8.083 & 0.010 & 0.705 & 0.020 & 1.117 & 0.318 & 0.082 & 569.617 & 3.213 & 0.252 & 4.500 & 0.560 \\
\hline II/A7 & 0.116 & 0.153 & -1.245 & 4.529 & 0.002 & 0.735 & \begin{tabular}{|l|}
0.031 \\
\end{tabular} & 0.689 & 0.320 & 0.018 & 483.924 & 4.153 & 0.772 & 4.000 & 0.510 \\
\hline$\vdots$ & $\vdots$ & $\vdots$ & $\begin{array}{l}\vdots \\
\end{array}$ & $\vdots$ & $\vdots$ & $\vdots$ & \begin{tabular}{|l|}
$\vdots$ \\
\end{tabular} & $\vdots$ & $\vdots$ & $\vdots$ & 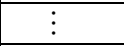 & $\vdots$ & $\vdots$ & $\vdots$ & $\vdots$ \\
\hline III/E13 & 0.649 & 0.753 & 0.029 & 3.172 & 0.004 & 0.754 & \begin{tabular}{|l|}
0.030 \\
\end{tabular} & 2.879 & 2.576 & 0.005 & 162.676 & 1.863 & 0.834 & 3.500 & 0.360 \\
\hline III/E14 & 0.688 & 0.853 & \begin{tabular}{|l|}
-0.099 \\
\end{tabular} & 3.220 & 0.004 & 0.782 & 0.017 & 3.187 & 2.391 & 0.017 & 478.359 & 10.768 & 1.270 & 4.000 & 0.410 \\
\hline III/E15 & 0.728 & 0.953 & -0.226 & 3.268 & 0.003 & 0.810 & 0.004 & 3.494 & 2.206 & 0.008 & 550.975 & 6.831 & 1.678 & 4.500 & 0.480 \\
\hline$\vdots$ & $\vdots$ & $\vdots$ & $\vdots$ & $\vdots$ & $\vdots$ & $\vdots$ & $\vdots$ & $\vdots$ & $\vdots$ & $\vdots$ & $\vdots$ & $\vdots$ & $\vdots$ & $\vdots$ & $\vdots$ \\
\hline IV/C6 & 0.491 & 0.656 & -0.301 & 4.404 & 0.002 & 0.724 & 0.029 & 3.135 & 2.527 & 0.009 & 67.542 & 1.107 & 1.684 & 4.500 & 0.510 \\
\hline IV/C7 & 0.457 & 0.612 & -0.121 & 4.330 & 0.001 & 0.726 & 0.025 & 2.963 & 2.782 & 0.013 & 97.146 & 2.663 & 1.240 & 3.500 & 0.430 \\
\hline IV/C9 & 0.468 & 0.598 & 0.152 & 3.293 & 0.005 & 0.786 & 0.018 & 2.309 & 2.109 & 0.019 & 89.291 & 0.938 & 0.884 & 6.500 & 0.590 \\
\hline
\end{tabular}

As mentioned in Sadowski (2012), Sadowski and Hoła (2013), it often happens in testing practice that one or more results is/are much different from the rest. A doubt arises whether the given result should be taken into account in the analysis of the distribution or whether it should be rejected. For this reason Chauvenet's criterion for eliminating uncertain results is used.

The Shapiro-Wilk test results for the particular parameters listed in Figure 2, after the application of Chauvenet's criterion and Spearman's rank correlation coefficient for the correlations between the particular parameters and the output variable (pull-off adhesion $\mathrm{fb}$ ), are presented in Table 2 .

On the basis of the statistical analyses, the following parameters determined using the three nondestructive techniques were selected as useful for the nondestructive identification of the pull-off adhesion between the concrete layers in floors by means of ANNs:

the average arithmetic deviation of the tested surface from the reference surface $\left(S_{\mathrm{a}}\right)$, the surface load-bearing capacity index $\left(S_{\mathrm{bi}}\right)$ and the mean square deviation of the tested surface from the reference surface $\left(S_{\mathrm{q}}\right)$, determined using the nondestructive optical technique;

stiffness $K_{\mathrm{d}}$ and average mobility $N_{\mathrm{av}}$, determined using the nondestructive impulse-response technique;

- the frequency of ultrasonic wave reflection from the bottom $\left(f_{\mathrm{T}}\right)$, determined using the nondestructive impact-echo technique.

Also the following parameters determined using two nondestructive techniques were selected as useful for the nondestructive identification of the pull-off adhesion between the concrete layers in floors by means of ANNs on the basis of the statistical analysis: the average arithmetic deviation of the tested surface from the reference surface $\left(S_{a}\right)$, the surface load-bearing capacity index $\left(S_{\mathrm{bi}}\right)$ and the mean square deviation of the tested surface from the reference surface $\left(S_{\mathrm{q}}\right)$, determined using the nondestructive optical technique;

-stiffness $K_{\mathrm{d}}$ and average mobility $N_{\mathrm{av}}$, determined using the nondestructive impulse-response technique.

The parameter determined using the impact-echo technique was omitted since its value directly depends on the thickness of the tested element.

Table 2. Shapiro-Wilk test results and Spearman's rank correlation coefficient $\rho_{\mathrm{s}}$

\begin{tabular}{c|c|c|c|c}
\hline Parameter name & $W$ & $\alpha$ & $W_{\mathrm{n}}(\alpha)$ & $\rho_{\mathrm{s}}$ \\
\hline$S_{\mathrm{a}}$ & 0.957 & 0.01 & 0.956 & -0.447 \\
\hline$S_{\mathrm{q}}$ & 0.958 & 0.01 & 0.956 & -0.446 \\
\hline$S_{\mathrm{sk}}$ & 0.983 & 0.01 & 0.956 & -0.116 \\
\hline$S_{\mathrm{ku}}$ & 0.877 & 0.01 & 0.956 & -0.052 \\
\hline$S_{\mathrm{bi}}$ & 0.630 & 0.01 & 0.956 & 0.204 \\
\hline$S_{\mathrm{ci}}$ & 0.550 & 0.01 & 0.956 & -0.077 \\
\hline$S_{\mathrm{vi}}$ & 0.913 & 0.01 & 0.956 & 0.176 \\
\hline$S_{\mathrm{v}}$ & 0.912 & 0.01 & 0.956 & -0.037 \\
\hline$S_{\mathrm{p}}$ & 0.881 & 0.01 & 0.956 & -0.067 \\
\hline$K_{\mathrm{d}}$ & 0.839 & 0.01 & 0.956 & 0.416 \\
\hline$N_{\mathrm{av}}$ & 0.617 & 0.01 & 0.956 & -0.711 \\
\hline$M_{\mathrm{p}} / N$ & 0.721 & 0.01 & 0.956 & -0.395 \\
\hline$v$ & 0.751 & 0.01 & 0.956 & 0.333 \\
\hline$f_{\mathrm{T}}$ & 0.964 & 0.01 & 0.956 & 0.925 \\
\hline$f_{\mathrm{b}}$ & 0.957 & 0.01 & 0.956 & - \\
\hline & & & &
\end{tabular}


The parameters were randomly divided into training data, testing data and data for the experimental verification of the artificial neural network. From among the 456 sets of results, 322 sets were adopted for training the ANN. 69 for testing the ANN and 69 for the experimental verification of the ANN.

\section{Numerical analyses by means of artificial neural networks}

From among the 96 configurations of artificial neural networks $\mathrm{A}, \mathrm{B}$ and $\mathrm{C}$ considered in Sadowski and Hoła (2013), network C was selected to be trained and tested for the nondestructive identification of pull-off adhesion $f_{\mathrm{b}}$. It is a unidirectional multilayer error back propagation network with the QUASI-NEWTON algorithm, 10 hidden layer neurons and the tanh hidden layer activation function. The adopted number of epochs was 200. The structure of the ANN is shown in Figure 9. The five parameters experimentally determined using respectively the three nondestructive techniques (Fig. 9a) and the two nondestructive techniques (Fig. 9b) form the ANN's input layer.

a)

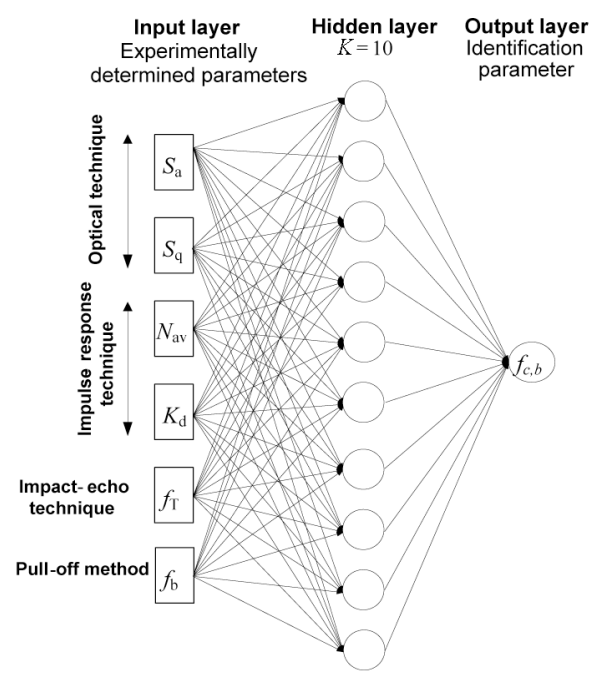

b)

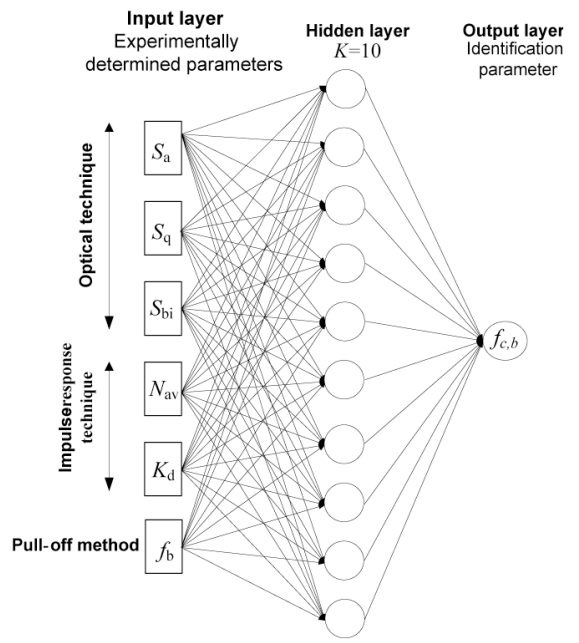

Fig. 9. Structure of ANN, adopted to be trained and tested from data acquired using respectively three nondestructive techniques (a) and two nondestructive techniques (b) a)

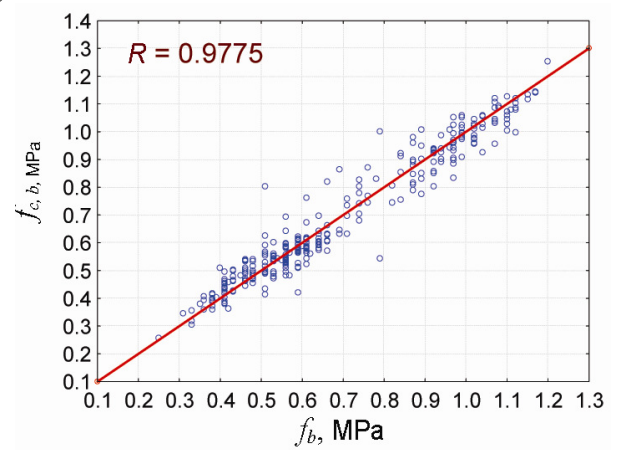

b)

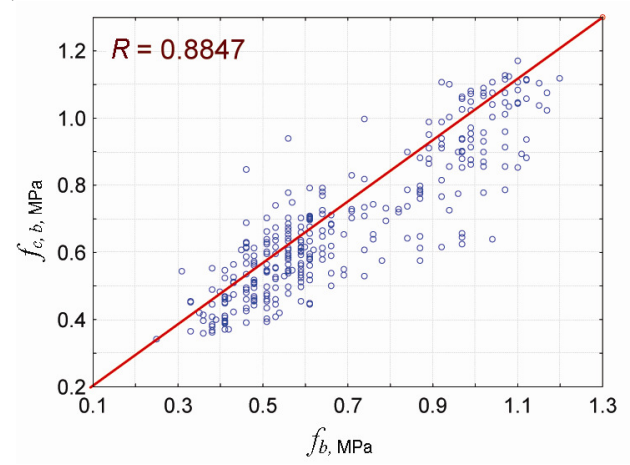

Fig. 10. Correlation between pull-off adhesion $f_{\mathrm{b}}$ experimentally determined by seminondestructive pull-off method and pull-off adhesion $f_{\text {c.b }}$ identified by network $\mathrm{C}$ in training for data acquired by three nondestructive techniques (a) and by two nondestructive techniques (b)

a)

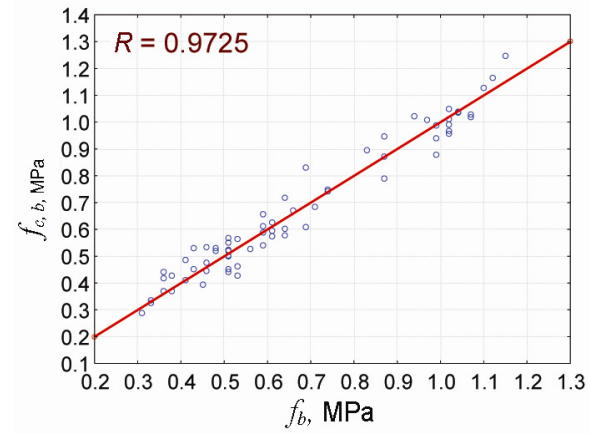

b)

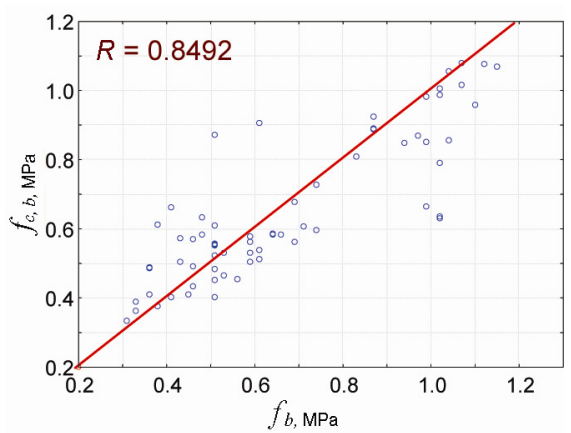

Fig. 11. Correlation between pull-off adhesion $f_{\mathrm{b}}$ experimentally determined by seminondestructive pull-off method and pull-off adhesion $f_{\text {c.b }}$ identified by network $\mathrm{C}$ in testing for data acquired by three nondestructive techniques (a) and by two nondestructive techniques (b) 
The ANN training and testing results are presented in Figures 10 and 11, respectively. It shows that network $\mathrm{C}$ accurately maps the training data and precisely identifies the testing data, as evidenced by the situation of the points along the regression line related to the ideal mapping. It is significant that very high linear correlation coefficient $R$ values were obtained for both training and testing, for the data acquired by the three nondestructive techniques: respectively 0.9775 and 0.9725 and by the two nondestructive techniques: respectively 0.8847 and 0.8492 .

\section{Results of experimental verification}

In order to experimentally verify network $C$ sixty nine sets of results were selected from all the test results. The previously trained and tested neural network was fed the values of parameters $S_{\mathrm{a}}, S_{\mathrm{q}}, N_{\mathrm{av}}, K_{\mathrm{d}}$ and $f_{\mathrm{T}}$ in each of the 69 randomly selected test points, including: 16 for surface I, 16 for surface II, 12 for surface III and 25 surface IV.

a)

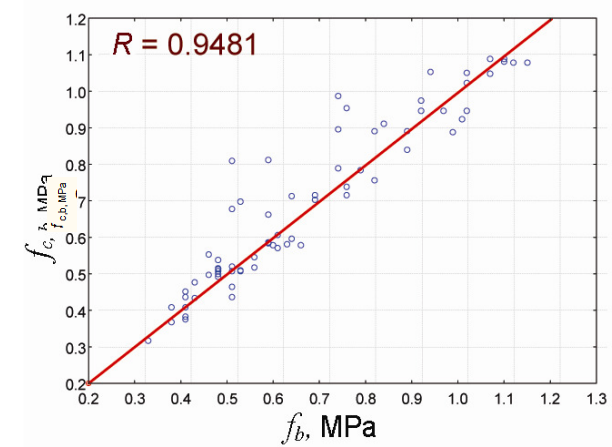

b)

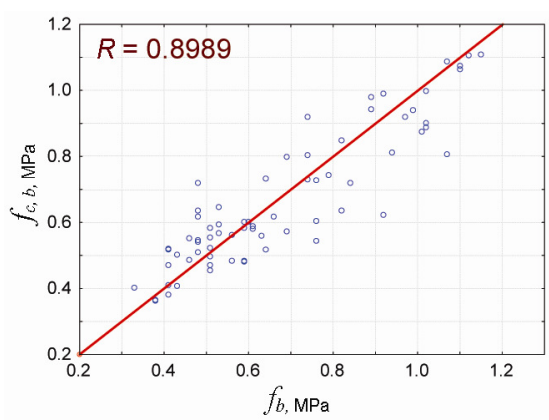

Fig. 12. Correlation between pull-off adhesion $f_{\mathrm{b}}$ experimentally determined by seminondestructive pull-off method and pull-off adhesion $f_{\text {c.b }}$ identified by network $\mathrm{C}$ in verification

Figure 12 presents the correlation between experimentally determined pull-off adhesion $f_{\mathrm{a}, \mathrm{b}}$ identified by network $\mathrm{C}$ in the verification. The results indicate that network $\mathrm{C}$ correctly identifies the randomly selected verification data, as evidenced by the situation of the points along the regression line related to the ideal mapping and by the high value of correlation coefficient $R$, equal to 0.9481 for the three nondestructive techniques and 0.8989 for the two nondestructive techniques.

\section{Conclusions}

The following conclusions have been drawn from the results of the experimental and numerical studies:

- The pull-off adhesion between the concrete layers in floors can be identified in the new nondestructive way on the basis of the parameters evaluated on the base layer surface, using the nondestructive optical technique, and on the floor surface, using the nondestructive acoustic impulse-response and impact-echo techniques, with data processing by means of an artificial neural network with a proper structure and training algorithm. The unidirectional multilayer error back propagation network with the QUASINEWTON algorithm was found to be most suitable for this purpose.

- The values of pull-off adhesion $f_{\mathrm{c}, \mathrm{b}}$ of the concrete layers in floors can be reliably identified on the basis of the values of parameters: $S_{\mathrm{a}}, S_{\mathrm{q}}, K_{\mathrm{d}}, N_{\mathrm{av}}$ and $f_{\mathrm{T}}$ determined using three nondestructive techniques: the optical technique and the acoustic impulseresponse and impact-echo techniques.

- Pull-off adhesion $f_{\mathrm{c}, \mathrm{b}}$ between the top layer and the base layer in floors can also be identified on the basis of the values of parameters $S_{\mathrm{a}}, S_{\mathrm{q}}, S_{\mathrm{bi}}, K_{\mathrm{d}}$ and $N_{\mathrm{av}}$ determined using two nondestructive techniques: the optical technique and one acoustic technique (the impulse-response technique), doing without parameter $f_{\mathrm{T}}$ dependent on the top layer thickness, determined using the impact-echo technique. However, linear correlation coefficient $R$, amounting to $0.8847,0.8492$ and 0.8989 for respectively training, testing and verification, is then much lower than when the three nondestructive techniques are used.

- The new way proposed in this paper is not intended to completely replace the currently commonly used identification of the pull-off adhesion between the concrete layers in floors by the seminondestructive pull-off method, but represents a new approach to the identification of this adhesion, in which trained and tested ANNs are employed for this purpose.

\section{References}

Błaszczyński, T.; Jasiczak, J.; Ksit, B.; Siewczyńska, M. 2006. Aspects of bond layer role in concrete repairs, Archives of Civil and Mechanical Engineering 6(4): 73-85. http://dx.doi.org/10.1016/S1644-9665(12)60277-5

Bungey, J.; Millard, S.; Gratham, M. 2006. Testing of concrete in structures. $4^{\text {th }}$ ed. London: Taylor \& Francis. $352 \mathrm{p}$.

Chien-Ho, K. 2013. Predicting subcontractor performance using web-based evolutionary fuzzy neural networks, The Scientific World Journal. Article ID 729525. 9 p.

Cwirzen, A.; Sztermen, P.; Habermehl-Cwirzen, K. 2014. Effect of Baltic seawater and binder type on frost durability of concrete, Journal of Materials in Civil Engineering 26(2): 283-287. http://dx.doi.org/10.1061/(ASCE)MT.1943-5533.0000803

Darowicki, K.; Mirakowski, A.; Krakowiak, S. 2003. Investigation of pitting corrosion of stainless steel by means of acoustic emission and potentiodynamic methods, Corrosion Science 45(8): 1747-1756.

http://dx.doi.org/10.1016/S0010-938X(03)00021-0 
Gołaski, L.; Goszczyńska, B.; Świt, G.; Trąmpczyński, W. 2012. System for the global monitoring and evaluation of damage processes developing within concrete structures under service loads, The Baltic Journal of Road and Bridge Engineering 7(4): 237-245.

http://dx.doi.org/10.3846/bjrbe.2012.32

Gonzalez-Jorge, H.; Solla, M.; Armesto, J.; Arias, P. 2012. Novel method to determine laser scanner accuracy for applications in civil engineering, Optica Applicata 17(1): 43-53.

Gorzelańczyk, T. 2012. Acoustically assessed influence of air pore structure on failure of self-compacting concretes under compression, Journal of Civil Engineering and Management 18(1): 60-70. http://dx.doi.org/10.3846/13923730.2011.652982

Grzelka, M.; Marciniak, L.; Gapinski, B.; Budzik, G.; Trafarski, A.; Augustyn-Pieniazek, J.; Gaca, M. 2012. Accuracy of the element geometry mapping using non-invasive computer tomography method, Journal of Automation Mobile Robotics and Intelligent Systems 6(3): 23-26.

Hasanzadehshooiili, H.; Lakirouhani, A.; Medzvieckas, J. 2012. Superiority of artificial neural networks over statistical methods in prediction of the optimal length of rock bolts, Journal of Civil Engineering and Management 18(5): $655-661$.

http://dx.doi.org/10.3846/13923730.2012.724029

Helmerich, R.; Niederleithinger, E.; Trela, C.; Bień, J.; Kamiński, T.; Bernardini, G. 2012. Multi-tool inspection and numerical analysis of an old masonry arch bridge, Structure and Infrastructure Engineering 8(1): 27-39. http://dx.doi.org/10.1080/15732471003645666

Hoła, J.; Sadowski, L. 2012. Testing interlayer pull-off adhesion in concrete floors by means of nondestructive acoustic methods, in The 18th World Conference on Nondestructive Testing, 16-20 April, 2012, Durban, South Africa. 8 p.

Hoła, J.; Sadowski, Ł.; Reiner, J.; Stankiewicz, M. 2012. Concrete surface roughness testing using nondestructive threedimensional optical method, in NDE for Safety/Defektoskopie, October 30-November 1, 2012, Seč u Chrudimi, Czech Republic, 101-106.

Hoła, J.; Sadowski, L.; Schabowicz, K. 2011. Nondestructive identification of delaminations in concrete floor toppings with acoustic methods, Automation in Construction 20(7): 799-807. http://dx.doi.org/10.1016/j.autcon.2011.02.002

Hoła, J.; Schabowicz, K. 2005. Methodology of neural identification of strength of concrete, ACI Materials Journal 102(6): 459-464.

Hoła, J.; Schabowicz, K. 2010. State-of-the-art non-destructive methods for diagnostic testing of building structures - anticipated development trends, Archives of Civil and Mechanical Engineering 10(3): 5-18.

http://dx.doi.org/10.1016/S1644-9665(12)60133-2

Łowińska-Kluge, A.; Błaszczyński, T. 2012. The influence of internal corrosion on the durability of concrete, Archives of Civil and Mechanical Engineering 12(2): 219-227. http://dx.doi.org/10.1016/j.acme.2012.03.002

Mathia, T.; Pawlus, P.; Wieczorowski, M. 2011. Recent trends in surface metrology, Wear 271: 494-508. http://dx.doi.org/10.1016/j.wear.2010.06.001

Maierhofer, C.; Krause, M.; Mielentz, F.; Streicher, D.; Milmann, B.; Gardei, A.; Kohl, C.; Wiggenhauser, H. 2004. Complementary application of radar, impact-echo, and ultrasonics for testing concrete structures and metallic tendon ducts, Transportation Research Record 1892(1): 170-177.
Naderi, M.; Ghodousian, O. 2012. Adhesion of self-compacting overlays applied to different concrete substrates and its prediction by fuzzy logic, The Journal of Adhesion 88(10): 848-865.

http://dx.doi.org/10.1080/00218464.2012.705673

Niemczewska-Wójcik, M.; Mańkowska-Snopczyńska, A.; Piekoszewski, W. 2013. The investigation of wear tracks with the use of noncontact measurement methods, Archives of Civil and Mechanical Engineering 13(2): 158-167. http://dx.doi.org/10.1016/j.acme.2013.01.005

Olofsson, J.; Elfgren, L.; Bell, B.; Paulsson, B.; Niederleithinger, E.; Jensen, J. S.; Feltrin, G.; Taljsten, B.; Cremona, C.; Kiviluoma, R.; Bień, J. 2005. Assessment of European railway bridges for future traffic demands and longer lives - EC project "Sustainable Bridges", Structure and Infrastructure Engineering 1(2): 93-100. http://dx.doi.org/10.1080/15732470412331289396

Pawlus, P.; Reizer, P.; Wieczorowski, M. 2013. The analysis of directionality of honed cylinder liners surfaces, Scanning 36(1): 95-104. http://dx.doi.org/10.1002/sca.21101

Perez, F.; Bissonnette, B.; Courard, L. 2009. Combination of mechanical and optical profilometry techniques for concrete surface roughness characterization, Magazine of Concrete Research 61(6): 389-400. http://dx.doi.org/10.1680/macr.2008.61.6.389

PN-EN 12636:2001 Wyroby $i$ systemy do ochrony i napraw konstrukcji betonowych. Metody badań. Oznaczanie przyczepności betonu do betonu [Products and systems for protecting and repairing concrete structures. Testing methods. Determination of concrete/concrete adhesion]. Poland: Polski Komitet Normalizacyjny. 10 p.

Raab, C.; Halim, A.; El Halim, O.; Part, M. 2013. Utilisation of artificial neural network for the analysis of interlayer shear properties, The Baltic Journal of Road and Bridge Engineering 8(2): 107-116. http://dx.doi.org/10.3846/bjrbe.2013.14

Sadowski, Ł. 2012. Nieniszczaca ocena zespolenia warstw betonowych $w$ podlogach $z$ wykorzystaniem sztucznych sieci neuronowych [Nondestructive evaluation of bond between concrete layers in floors by means of artificial neural networks]: PhD thesis. Wroclaw: Wroclaw University of Technology.

Sadowski, Ł. 2013a. Non-destructive evaluation of the pull-off adhesion of concrete floor layers using RBF neural Network, Journal of Civil Engineering and Management 19(4): 550-560. http://dx.doi.org/10.3846/13923730.2013.790838

Sadowski, Ł. 2013b. Non-destructive investigation of corrosion current density in steel reinforced concrete by artificial neural networks, Archives of Civil and Mechanical Engineering 13(1): 104-111. http://dx.doi.org/10.1016/j.acme.2012.10.007

Sadowski, Ł. 2013c. Analiza wpływu chropowatości podkładu betonowego na przyczepność na odrywanie warstwy wierzchniej [Analysis of the effect of concrete base roughness on the pull-off adhesion of the topping layer], IAPGOŚ 1: 39-42.

Sadowski, L.; Hoła, J. 2013. Neural prediction of the pull-off adhesion of the concrete layers in floors on the basis of nondestructive tests, Procedia Engineering 57: 986-995. http://dx.doi.org/10.1016/j.proeng.2013.04.125

Sansalone, M.; Streett, W. 1997. Impact-echo: nondestructive evaluation of concrete and masonry. Ithaca: Bullbrier Press. 339 p. 
Santos, P.; Julio, E. 2013. A state-of-the-art review on roughness quantification methods for concrete surfaces, Construction and Building Materials 38: 912-923. http://dx.doi.org/10.1016/j.conbuildmat.2012.09.045

Sezen, H.; Fisco, N. 2013. Evaluation and comparison of surface macrotexture and friction measurement methods, Journal of Civil Engineering and Management 19(3): 387399. http://dx.doi.org/10.3846/13923730.2012.746237

Shapiro, S.; Wilk, M. 1965. An analysis of variance test for normality, Biometrika 52: 591-611. http://dx.doi.org/10.2307/2333709

Siewczyńska, M. 2012. Method for determining the parameters of surface roughness by usage of a 3D scanner, Archives of Civil and Mechanical Engineering 1(2): 83-89. http://dx.doi.org/10.1016/j.acme.2012.03.007

Song, Y.; Yu, Z. 2013. Springback prediction in T-section beam bending process using neural networks and finite element method, Archives of Civil and Mechanical Engineering 13(2): 229-241. http://dx.doi.org/10.1016/j.acme.2012.11.004

Srinivas, V.; Sasmal, S.; Ramanjaneyulu, K.; Jeyasehar, C. 2013. Influence of test conditions on modal characteristics of reinforced concrete structures under different damage scenarios, Archives of Civil and Mechanical Engineering 13(4): 491-505.

http://dx.doi.org/10.1016/j.acme.2013.04.006
Stach, S.; Cwajna, J.; Roskosz, S.; Cybo, J. 2005. Multifractal description of fracture morphology: quasi 3D analysis of fracture surfaces, Materials Science - Poland 23(2): 573581 .

Stawiski, B. 2012. The heterogeneity of mechanical properties of concrete in formed constructions horizontally, Archives of Civil and Mechanical Engineering 12(1): 90-94. http://dx.doi.org/10.1016/j.acme.2012.03.006

Trapko, T.; Musiał, M. 2011. The effectiveness of CFRP materials strengthening of eccentrically compressed reinforced concrete columns, Archives of Civil and Mechanical Engineering 11(1): 249-262. http://dx.doi.org/10.1016/S1644-9665(12)60187-3

Twardowski, P.; Wojciechowski, S.; Wieczorowski, M.; Mathia, T. 2011. Surface roughness analysis of hardened steel after high-speed milling, Scanning 33(5): 386-395. http://dx.doi.org/10.1002/sca.20274

Wieczorowski, M.; Cellary, A.; Majchrowski, R. 2010. The analysis of credibility and reproducibility of surface roughness measurement results, Wear 269(5-6): 480-484. http://dx.doi.org/10.1016/j.wear.2010.05.003

Lukasz SADOWSKI. (PhD, Eng), a Researcher at Wrocław University of Technology, Poland. Received his PhD in 2013 at Wrocław University of Technology. He is a Research Assistant at WUT, Institute of Building Engineering. Research interests: concrete (especially concrete floors), non-destructive tests, acoustic techniques and artificial intelligence.

Jerzy HOLA. Full Professor at the Wrocław University of Technology, Dean of the Faculty of Civil Engineering, Head of the Department of General Building Engineering, and Director of the Accredited Research Laboratory at the Institute of Building Engineering. He is a member of the following organizations among others: Senate of the Wrocław University of Technology, Council of the Faculty of Civil Engineering, Section of Engineering Construction Materials the Committee of Civil Engineering Polish Academy of Sciences, Committee of Mechanics and Civil Engineering at the Polish Academy of Sciences Wrocław, Science Committee of PZITB (Polish Association of Building Engineers and Technicians), and the program board of the magazine "Builder". 